Journal of Education and Educational Development

7(2), 387-406, 2020

DOI: http://dx.doi.org/10.22555/joeed.v7i2.6

\title{
Regression Model on Self-Esteem, Self-Efficacy, Locus of Control as Predictors of Academic Performance of students in Higher Education
}

\author{
Javeria Waseem \\ jia_waseem@live.com \\ Department of Teacher Education, UoK, Pakistan \\ Muhammad Asim \\ muhammadasim@uok.edu.pk \\ University of Karachi, Pakistan
}

\begin{abstract}
This research computed the combined effects of self-esteem, self-efficacy, and locus of control as predictors of academic performance of students in different universities of Karachi by using the Regression model. Previous researches were correlational studies in nature and reported the moderate positive correlations between the variables self-esteem, self-efficacy, and locus of control and academic performance. A questionnaire with 40 items related to self-esteem, self-efficacy, locus of control, and academic performance was designed. The data was collected from the public and private universities of Karachi. Descriptive Statistics, t-test, Correlation, and Regression were calculated through SPSS. The regression model showed that self-esteem, self-efficacy, Locus of Control significantly predicted the academic performance of the graduate students. In Structural Equation Modeling self-efficacy contributed more to the academic performance of students. This research recommends more future researches for in-depth analysis of latent variables as the idea has not researched its maturity in the context of higher education in Pakistan.
\end{abstract}

Keywords: academic performance, higher education, locus of control, mental health, psycho-social determinants, self-efficacy, self-esteem, social support mechanism 


\section{Introduction}

Across the globe, in higher education, students face difficulties in maintaining balance among academic stress, personal issues, and their social and emotional wellbeing (Karaman \& Watson, 2017; Wokoma et al., 2019). This scenario influences the student's academic performance; hampers the students 'abilities to reach maximum potential and interferes with their daily life activities and their mental health (Debs et al., 2015). The academic performance of students in higher education is highly affected by the psychological and behavioral forces related to their self-esteem, self-efficacy, and locus of control (Arshad et al., 2015; Safaria \& Ahmad, 2013; Masud et al., 2016).

This research computes the combined effects of self-esteem, self-efficacy, and locus of control as predictors of academic performance of students using a Regression model to analyze student responses in different public and private sector universities of Karachi, Pakistan.

Jackson et al. (2000) reported that graduate students often dealt with a lack of academic motivation related to their self-esteem, locus of control, and daily life endeavors. Students' self-esteem, optimism, academic success, self-concept, and self-efficacy leads them toward academic procrastination that weakens their academic performance (Findley \& Cooper, 1983; Nilson-Whitten, et al., 2007). Students experience an extraordinary assortment of low self-worth, weak task-related-motivation, and negative social feelings in scholarly settings (Pekrun et al., 2002) of higher education.

Ahmed and Jabeen (2011) claimed that self-efficacy was an unexplored area from the academic point of view in the context of Pakistan and recommended more research in the future. Asim and Akbar, (2012) found ineffective and dysfunctional counseling services and the absence of a support mechanism to facilitate the current tier of students for their academic success in higher educational institutes of Karachi. Damani (2018) also observed that faculty members in different universities placed less emphasis on the physical and social wellbeing of their students and often ignored the mental wellbeing of students related to social stigma, ridiculing, and cultural insensitivities. Very few opportunities are given to students from their teachers and parents to explore their 
social and mental wellbeing (Synder, 2016). Hence, there is a lack of counseling services available to students to improve their social and emotional state and their academic performance.

Many pieces of research in the context of Pakistan such as Zahra, (2010); Akram and Ghazanfar, (2014); Hasan \& Khalid, (2014); Farhan and Khan, (2015); Shahid et al., (2016); Karaman and Watson, (2017) merely reported the correlation between one or two variables of self-esteem or self-efficacy or locus of control with academic performance of the students. These researches did not try to predict the combined effects of self-esteem, self-efficacy, and Locus of Control on the academic performance of students in public and private universities in Karachi, Pakistan. Hence, this research measures the combined effect of self-esteem, self-efficacy, and locus of control as predictors of academic performance for students in different universities of Karachi, Pakistan.

This research will be helpful for faculty members, parents, and the competent authorities of different universities to understand the issues related to psycho-social Determinants while keeping the cultural stigmas and sensitivities in perspective.

\section{Research Question}

1) How can self-esteem, self-efficacy, and locus of control predict the academic performance of the students in public and private universities in Karachi, Pakistan?

\section{Research Objectives}

To build the regression model of self-esteem, self-efficacy, and locus of control as the predictors of Academic Performance of students in different universities of Karachi, Pakistan.

\section{Research Hypothesis}

Ho1: There is no significant difference in the opinion of male and female students currently enrolled in higher education institutes in Karachi related to self-esteem, self-efficacy, locus of control, and academic performance. 


\section{$\mathrm{H}_{01}: \boldsymbol{\mu}_{\mathrm{m}}=\boldsymbol{\mu \mathrm { f }}$}

$\mathrm{H}_{\mathrm{o} 2}$ : There is no significant difference in the opinion of students enrolled in public and private universities in Karachi related to their self-esteem, Self-Efficacy, and locus of control and academic performance.

\section{Ho2: $\boldsymbol{\mu}$ Public Universities $=\mu$ Private Universities}

$\mathrm{H}_{03}$ : There is no significant effect of self-esteem, self-efficacy, locus of control can be predicted on academic performance of the students in graduate programs of different universities in Karachi, Pakistan.

Academic Performance $\neq b_{1}$ (self-esteem $)+b_{2}$ (self-efficacy) $+b_{3}$ (Locus of control) $+\mathrm{C}$

\section{Literature Review}

Hackett et al., (1992) observed that many teachers and faculty members in the US in different modules and programs were unable to uplift the self-efficacy among undergraduates to deal with their academic stress, social issues, and personal problems. Hackett et al. suggested that "Attention must be given to these important predictors including proactive efforts to enhance self-efficacy and provide support by counselors, administrators, and academic departments should serve to increase the probabilities for the success of all students" (p. 537). Sterbin and Rakow, (1996) reported that self-esteem was correlated with socioeconomic status and gender of the students. The locus of control also predicted better academic performance among the students in the United States. In Hong Kong, Zhang and Postiglione, (2001) found that among the graduate students those who showed weaker self-esteem related to the poor social and financial status influenced negatively on their self-perception and adversely affected their academic performance. These initial researches emphasized the notion of self-esteem and ignored the role of self-efficacy and locus of control in the academic success of students. Latter researches proved that self-efficacy and locus of control helped students to gain self-confidence, enabled them to take academic risks, and formed a habit to challenge their academic norms (Dontoh et al., 2018).

Kanwal (2006) in doctoral research in Pakistan also confirmed that students with sound financial, social, and physical attributes portrayed a higher level of 
self-esteem that increased their social and physical acceptance and showed better academic performance. Further, male students showed a higher locus of control in comparison to female students and the students of public sector universities had a higher locus of control than private sector universities.

Kanwal observed that students' engagement in cooperative learning and group-work positively contributed to the raise of self-efficacy and self-esteem of the graduate students and helped them to effectively cope-up with academic stress. Farhan and Khan, (2015) in another research in Karachi reported different research findings than Kanwal (2006). Farhan \& Khan found that students in private sector universities exhibited low stress and enjoyed higher self-esteem due to their liberal and flexible academic surroundings than the students of public sector universities in Karachi. Zaidi and Mohsin, (2013) reported that locus of control and academic self-efficacy were positively correlated among the students in private sector universities in Pakistan. Mustafa et al., (2010) noticed the absence of parental involvement in higher education in Pakistan. Parental support might serve as a buffer to reduce depression and could enhance the motivation of students to perform well in academics. Zahra (2010) stated that academic performance of the graduate students could not be interpreted without understanding of latent confounding variables. Hence, future researches should measure the combined effects of self-efficacy, self-esteem, locus of control in conjunction with the age, gender, socio-economic status and academic milieu in which the students pursued their lessons (Damani, 2018).

Benitez (2017) observed an indecisiveness regarding the academic preferences and choices among students with low self-efficacy. Snyder (2016) noticed that students with low self-esteem take refuge under peer social support to uplift their academic self-esteem. Snyder recommended the counselling therapy sessions to eradicate the root causes of weak self-esteem and poor academic performance. Akram and Ghazanfar, (2014) suggested a training program to help teachers to facilitate the students with low self-efficacy. "The teachers can be trained to improve the self-efficacy of their students by adopting different teaching strategies like collaborative teaching, peer learning and so on with special focus on female students" (Akram \& Ghazanfar., 2014, p. 288).

Dontoh et al., (2018) suggested the organization build a capacity of 
guidance to address the social self-concept of students and to employ a wide-scale mixed method research to understand the students' issues and academic point of view. Wokoma et al., (2019) also recommended the proactive role of institutions to address scholarly self-idea, student uneasiness, scholastic strength of students and to motivate students to perform efficiently in their academics.

A limited review of literature revealed that in Pakistan there was a lack of research to suggest the building of organizational database to maintain a record regarding the provision of counselling services to the students, its timely follow-up mechanism and building a social support system for students in the universities. Hence, many students who are prone to mental and social issues enter in their graduate studies without social and emotional support by counselors, their parents, faculty members and organizational administration.

\section{Methodology}

A survey was conducted to measure the opinion of graduate students of different public and private universities situated in district East, district Centre and district South of Karachi. A questionnaire was designed bearing the 40 items related to the variables self-esteem, self-efficacy, locus of control and academic performance of the students along with demographic information of the participants including their age, gender, and socio-economic status as suggested in the literature.

The reliability of the scales through Cronbach's Alpha value were for the self-esteem .569, self-efficacy .582, locus of control .627 and academic performance .319 and were computed through SPSS. Six hundred forms were distributed among the participants on one to one basis after seeking the permission of management in different universities. Five hundred and twenty-seven surveys were received and fed in SPSS (Statistical Package of Social Sciences). SPSS was used to draw $85 \%$ sample $(n=452)$ through random sampling method.

All ethical principles and considerations were followed before and after the data collection phases. Descriptive Statistics, Correlation, Independent Sample t-test and Regression model were applied on the variables self-esteem, self-efficacy, locus of control to predict the academic performance of the students 
in public and private sectors universities in Karachi. AMOS was used for Structural Equation Modeling (SEM) of self-esteem, self-efficacy and locus of control to predict the academic performance of the students in public and private sectors universities in Karachi.

\section{Figure 1}

\section{Findings}

Bar Graph between Gender and Institutions of Karachi

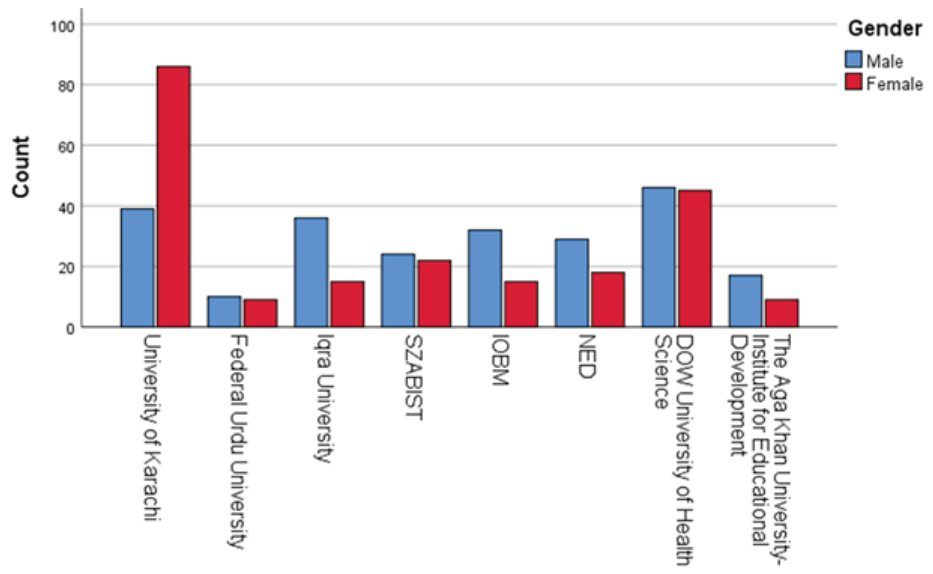

Note: the University of Karachi, NED, and Dow University of Health Sciences are operated and run under Sindh province jurisdiction. Federal Urdu University is run under the auspices of the Federal Government of Pakistan. Iqra University, SZABIST, IoBM, and The Aga Khan University Institute for Educational Development are private sector universities in Karachi.

Fig1 shows $62.38 \%$ of participants belonged to public sector universities and $37.62 \%$ of participants belonged to private sector universities of Karachi respectively. Also shown in Figure 1, $28.1 \%$ of the participants belonged to the University of Karachi, $3.8 \%$ of participants belonged to Federal Urdu University, $11.1 \%$ of participants belonged to Iqra University, $10.4 \%$ of participants belonged to SZABIST, $10.2 \%$ of participants belonged to IoBM, $10 \%$ of participants belonged to NED University, $20.6 \%$ of participants belonged to Dow University of Health Sciences and $6 \%$ of participants belonged to The Aga Khan University - Institute for Educational Development. The administration in public sector universities extended their cooperation by allowing their students to participate in a large number than private sector universities. 


\section{Table 1}

\section{Cross-tabulation between Gender and Faculties in Higher Education}

\begin{tabular}{llcccccc}
\hline & \multicolumn{5}{c}{ Faculties in Higher Education } & \\
\cline { 3 - 7 } & & $\begin{array}{c}\text { Social } \\
\text { Sciences }\end{array}$ & $\begin{array}{c}\text { Management } \\
\text { Sciences }\end{array}$ & Medical & Engineering & $\begin{array}{c}\text { Media } \\
\text { Sciences }\end{array}$ & Total \\
\cline { 3 - 8 } Gender & Male & 52 & 60 & 46 & 28 & 46 & 232 \\
\cline { 2 - 8 } Total & Female & 68 & 64 & 47 & 17 & 24 & 220 \\
\cline { 2 - 8 } & & 120 & 124 & 93 & 45 & 70 & 452 \\
\hline
\end{tabular}

Table 1 presents the cross-tabulation of students' participation from different academic disciplines of higher education. The students of social sciences, management sciences, and media sciences respectively participated in higher numbers than the students natural and applied sciences disciplines.

\section{Table 2}

Information Acquired Related to Psycho-Social Wellbeing of Students in universities of Karachi

\begin{tabular}{|c|c|c|c|}
\hline Name of Institution & & $\mathrm{f}$ & $\%$ \\
\hline University of Karachi & $\begin{array}{l}\text { No information was } \\
\text { acquired from students } \\
\text { related to their Psycho- } \\
\text { Social Wellbeing }\end{array}$ & 125 & 100.0 \\
\hline $\begin{array}{l}\text { Federal Urdu } \\
\text { University }\end{array}$ & $\begin{array}{l}\text { No information was } \\
\text { acquired from students } \\
\text { related to their Psycho- } \\
\text { Social Wellbeing }\end{array}$ & 19 & 100.0 \\
\hline Iqra University & $\begin{array}{l}\text { No information was } \\
\text { acquired from students } \\
\text { related to their Psycho- } \\
\text { Social Wellbeing }\end{array}$ & 51 & 100.0 \\
\hline SZABIST & $\begin{array}{l}\text { No information was } \\
\text { acquired from students } \\
\text { related to their Psycho- } \\
\text { Social Wellbeing }\end{array}$ & 46 & 100.0 \\
\hline IoBM & $\begin{array}{l}\text { No information was } \\
\text { acquired from students } \\
\text { related to their Psycho- } \\
\text { Social Wellbeing }\end{array}$ & 47 & 100.0 \\
\hline NED & $\begin{array}{l}\text { No information was } \\
\text { acquired from students } \\
\text { related to their Psycho- } \\
\text { Social Wellbeing }\end{array}$ & 47 & 100.0 \\
\hline $\begin{array}{l}\text { DOW University of } \\
\text { Health Science }\end{array}$ & $\begin{array}{l}\text { No information was } \\
\text { acquired from students } \\
\text { related to their Psycho- } \\
\text { Social Wellbeing }\end{array}$ & 91 & 100.0 \\
\hline $\begin{array}{l}\text { The Aga Khan } \\
\text { University-Institute for } \\
\text { Educational } \\
\text { Development }\end{array}$ & $\begin{array}{l}\text { Some information was } \\
\text { acquired from students } \\
\text { related to their Psycho- } \\
\text { Social Wellbeing during and } \\
\text { after admission process }\end{array}$ & 26 & 100.0 \\
\hline & Total & 452 & \\
\hline
\end{tabular}


Table 2 reveals that only The Aga Khan University-Institute for educational development maintains the information related to the psycho-social wellbeing of their graduate students at the beginning of their academic program.

\section{Table 3}

Academic Performance, Self-Esteem, Self-Efficacy, and Locus of Control from the Opinion of Gender

\begin{tabular}{lllccc}
\hline Variable & Gender & $\mathrm{N}$ & $\mathrm{M}$ & SD & SEM \\
\hline Academic Performance & Male & 232 & 7.37 & 0.68 & 0.04 \\
\cline { 2 - 6 } & Female & 220 & 7.45 & 0.71 & 0.05 \\
\hline \multirow{2}{*}{ Self-Esteem } & Male & 232 & 28.73 & 4.48 & 0.29 \\
\cline { 2 - 6 } & Female & 220 & 29.09 & 4.42 & 0.30 \\
\hline Self-Efficacy & Male & 232 & 6.26 & 0.73 & 0.05 \\
\cline { 2 - 6 } & Female & 220 & 6.31 & 0.82 & 0.06 \\
\hline Locus of Control & Male & 232 & 31.60 & 4.44 & 0.29 \\
\cline { 2 - 6 } & Female & 220 & 31.94 & 4.45 & 0.30 \\
\hline
\end{tabular}

In Table 3 male and female participants expressed minor differences in their opinion in terms of mean and standard deviation scores related to academic performance, self-esteem, self-efficacy and locus of control.

\section{Table 4}

Opinion of the Male and Female students about Academic Performance, Self-Esteem, Self-Efficacy and Locus of Control

\begin{tabular}{|c|c|c|c|c|c|c|c|c|c|}
\hline & \multirow{2}{*}{$\mathrm{F}$} & \multirow{2}{*}{$p$} & \multirow{2}{*}{$t$} & \multirow{2}{*}{$\mathrm{df}$} & \multirow{2}{*}{$p$} & \multirow{2}{*}{$M D$} & \multirow{2}{*}{ SED } & \multicolumn{2}{|c|}{$\begin{array}{l}95 \% \text { Confidence } \\
\text { Interval of the } \\
\text { Difference }\end{array}$} \\
\hline & & & & & & & & Lower & Upper \\
\hline $\begin{array}{l}\text { Academic } \\
\text { Performance }\end{array}$ & 0.09 & 0.77 & -1.23 & 450 & 0.22 & -0.08 & 0.07 & -0.21 & 0.05 \\
\hline Self-Esteem & 0.09 & 0.77 & -0.85 & 450 & 0.39 & -0.36 & 0.42 & -1.18 & 0.47 \\
\hline Self-Efficacy & 2.64 & 0.10 & -0.78 & 450 & 0.43 & -0.06 & 0.07 & -0.20 & 0.09 \\
\hline $\begin{array}{l}\text { Locus of } \\
\text { Control }\end{array}$ & 0.00 & 0.95 & -0.81 & 450 & 0.42 & -0.34 & 0.42 & -1.16 & 0.48 \\
\hline
\end{tabular}


In Table 4 for the variables academic performance $t(450)=-1.23$ where $p$ $=0.22>0.05$, Self-Esteem $\mathrm{t}(450)=-0.85$ where $\mathrm{p}=0.39>0.05$, self-efficacy $\mathrm{t}$ $(450)=-0.78$ where $p=0.43>0.05$ and locus of control $t(450)=-0.81$ where $p$ $=0.42>0.05$. Hence, there is no significant difference in the opinion of male and female participants regarding academic performance, self-efficacy, self-esteem and locus of control.

\section{Table 5}

Academic Performance, Self-Esteem, Self-Efficacy and Locus of Control from the opinion of students of Public and Private Sector Universities

\begin{tabular}{lll|c|c|c}
\hline Variable & Organization type & $\mathrm{N}$ & $\mathrm{M}$ & $S D$ & SEM \\
\hline Academic Performance & Public t & 282 & 7.47 & 0.71 & 0.04 \\
\cline { 2 - 6 } Self-Esteem & Private & 170 & 7.31 & 0.65 & 0.05 \\
\cline { 2 - 6 } & Public & 282 & 29.41 & 4.42 & 0.26 \\
\cline { 2 - 6 } Self-Efficacy & Private & 170 & 28.06 & 4.39 & 0.34 \\
\cline { 2 - 6 } & Public t & 282 & 6.37 & 0.78 & 0.05 \\
\cline { 2 - 6 } Locus of Control & Private & 170 & 6.13 & 0.75 & 0.06 \\
\cline { 2 - 6 } & Public & 282 & 31.81 & 4.48 & 0.27 \\
\cline { 2 - 6 } & Private & 170 & 31.70 & 4.39 & 0.34 \\
\hline
\end{tabular}

In Table 5 students from public and private sector universities expressed a difference in their opinion in terms of mean and standard deviation scores related to academic performance, self-esteem, self-efficacy and locus of control.

\section{Table 6}

Opinion of the Students of Public and Private Universities about Academic Performance, Self-Esteem, Self-Efficacy and Locus of Control

\begin{tabular}{|c|c|c|c|c|c|c|c|c|c|}
\hline & \multirow[b]{2}{*}{$\mathrm{F}$} & \multirow[b]{2}{*}{$p$} & \multirow[b]{2}{*}{$t$} & \multirow[b]{2}{*}{$\mathrm{df}$} & \multirow[b]{2}{*}{$p$} & \multirow[b]{2}{*}{ MD } & \multirow[b]{2}{*}{ SED } & \multicolumn{2}{|c|}{$\begin{array}{l}95 \% \text { Confidence } \\
\text { Interval of the } \\
\text { Difference }\end{array}$} \\
\hline & & & & & & & & Lower & Upper \\
\hline $\begin{array}{l}\text { Academic } \\
\text { Performance }\end{array}$ & 2.45 & 0.12 & 2.39 & 450 & 0.02 & 0.16 & 0.07 & 0.03 & 0.29 \\
\hline Self-Esteem & 0.01 & 0.91 & 3.14 & 450 & 0.00 & 1.34 & 0.43 & 0.50 & 2.18 \\
\hline $\begin{array}{l}\text { Self- } \\
\text { Efficacy }\end{array}$ & 0.22 & 0.64 & 3.24 & 450 & 0.00 & 0.24 & 0.07 & 0.09 & 0.39 \\
\hline $\begin{array}{l}\text { Locus of } \\
\text { Control }\end{array}$ & 0.01 & 0.91 & 0.25 & 450 & 0.80 & 0.11 & 0.43 & -0.74 & 0.96 \\
\hline
\end{tabular}


In Table 6 for the variables academic performance $\mathrm{t}(450)=2.39$ where $\mathrm{p}=$ $0.02<0.05$, self-esteem $\mathrm{t}(450)=3.14$ where $\mathrm{p}=0.00<0.05$, self-efficacy $\mathrm{t}(450)$ $=3.24$ where $\mathrm{p}=0.00<0.05$ and locus of control $\mathrm{t}(450)=0.25$ where $\mathrm{p}=0.80>$ 0.05 . Hence, there is a significant difference in the opinion of students in public and private universities in Karachi regarding academic performance, self-esteem and self-efficacy. However, there is no significant difference in the opinion of students in public and private universities observed in the variable locus of control.

\section{Table 7}

Correlation among Academic Performance, Self-Efficacy, Self-Esteem and Locus of Control

\begin{tabular}{|c|c|c|c|c|c|}
\hline & & $\begin{array}{l}\text { Academic } \\
\text { Performance }\end{array}$ & Self-Esteem & Self-Efficacy & $\begin{array}{l}\text { Locus of } \\
\text { Control }\end{array}$ \\
\hline \multirow{4}{*}{$\begin{array}{l}\text { Academic } \\
\text { Performance }\end{array}$} & $r$ & 1 & $.360^{* *}$ & $.350^{* *}$ & $.399^{* *}$ \\
\hline & $r^{2}$ & & 12.96 & 12.25 & 15.92 \\
\hline & $p$ & & 0.000 & 0.000 & 0.000 \\
\hline & $\mathrm{N}$ & & 452 & 452 & 452 \\
\hline \multirow{4}{*}{ Self-Esteem } & $r$ & & 1 & $.336^{* *}$ & $.207^{* *}$ \\
\hline & $r^{2}$ & & & 11.29 & 4.28 \\
\hline & $p$ & & & 0.000 & 0.000 \\
\hline & $\mathrm{N}$ & & & 452 & 452 \\
\hline \multirow{2}{*}{ Self-Efficacy } & $r$ & & & 1 & $.254^{* *}$ \\
\hline & $r^{2}$ & & & & 6.4 \\
\hline \multirow{6}{*}{ Locus of Control } & $p$ & & & & 0.000 \\
\hline & $\mathrm{N}$ & & & & 452 \\
\hline & $r$ & & & & 1 \\
\hline & $r^{2}$ & & & & \\
\hline & $p$ & & & & \\
\hline & $\mathrm{N}$ & & & & \\
\hline
\end{tabular}

Note: **. Correlation is significant at the 0.01 level (2-tailed). 
In Table 7 the correlation among the variables academic performance, self-efficacy, self-esteem and locus of control were statically significant $(p=0.01)$. The contribution of self-esteem in the variance account of academic performance is $(\mathrm{r} 2=12.96 \%)$, the contribution of self-efficacy in the variance account of academic performance is $(\mathrm{r} 2=12.25 \%)$ and the contribution of locus of control in the variance in academic performance is ( $\mathrm{r} 2=15.92 \%)$. However, there is a weak and a positive correlation between self-efficacy and self-esteem $(r=.336)$, a weak and a positive correlation between self-esteem and locus of control $(r=.207)$ and a positive and weak correlation between self-efficacy and locus of control $(r=.254)$ observed.

\section{Table 8}

Regression Model for the variables Self-Efficacy, Self-Esteem and Locus of Control as predictors of Academic Performance

\begin{tabular}{|c|c|c|c|c|c|c|c|c|c|}
\hline \multirow[b]{2}{*}{ Model } & \multirow[b]{2}{*}{$\mathrm{R}$} & \multirow[b]{2}{*}{$\begin{array}{c}\mathrm{R} \\
\text { Square }\end{array}$} & \multirow[b]{2}{*}{$\begin{array}{c}\text { Adjusted R } \\
\text { Square }\end{array}$} & \multirow[b]{2}{*}{ SES } & \multicolumn{5}{|c|}{ Change Statistics } \\
\hline & & & & & $\begin{array}{c}\text { R Square } \\
\text { Change }\end{array}$ & $\begin{array}{c}\mathrm{F} \\
\text { Change }\end{array}$ & df1 & $\mathrm{df} 2$ & $p$ \\
\hline 1 & $.522 \mathrm{a}$ & .272 & .267 & .585 & .272 & 55.87 & 3 & 448 & .000 \\
\hline
\end{tabular}

Note:

a. Predictors: (Constant), Locus of Control, Self-Esteem, Self-Efficacy

b. Dependent Variable: Academic Performance

Table 8 presents the enter method of regression model for the variables self-efficacy, self-esteem and locus of control as predictors of academic performance. The model is significant in such a way that $\mathrm{R}=.522, \mathrm{R} 2=.272$ and $\mathrm{F}(3,448)=55.87$ where $\mathrm{p}=.000$.

\section{Table 9}

Coefficient Table for the variables Self-Efficacy, Self-Esteem and Locus of Control as predictors of Academic Performance

\begin{tabular}{|c|c|c|c|c|c|c|}
\hline \multirow[b]{2}{*}{ Model } & & \multicolumn{2}{|c|}{$\begin{array}{l}\text { Unstandardized } \\
\text { Coefficients }\end{array}$} & $\begin{array}{l}\text { Standardized } \\
\text { Coefficients }\end{array}$ & \multirow[b]{2}{*}{$t$} & \multirow[b]{2}{*}{$p$} \\
\hline & & $\beta$ & $S D E$ & & & \\
\hline \multirow[t]{4}{*}{1} & Constant & 3.842 & .278 & & 13.803 & .00 \\
\hline & Self-Esteem & .034 & .006 & .228 & 5.291 & .00 \\
\hline & Self-Efficacy & .173 & .038 & .200 & 4.600 & .00 \\
\hline & $\begin{array}{l}\text { Locus of } \\
\text { Control }\end{array}$ & .05 & .006 & .302 & 7.179 & .00 \\
\hline
\end{tabular}

Note: Dependent Variable: Academic Performance 
In Table 9 the equation for regression model shows for the variables self-esteem, self-efficacy, locus of control are the significant predictors of academic performance of the students in higher education. As shown in equation (1), an increase in .034 unit in self-esteem, .173 unit increase in self-efficacy and 0.05 unit increase in locus of control would increase one unit of academic performance of the students in higher education.

$$
\mathrm{AP}=.034 \mathrm{SE}+.173 \mathrm{SEf}+.05 \mathrm{LoC}+3.84
$$

\section{Figure 2}

Structural Equal Modeling of Self-Esteem, Self-Efficacy, Locus of Control as Predictors of Academic Performance.

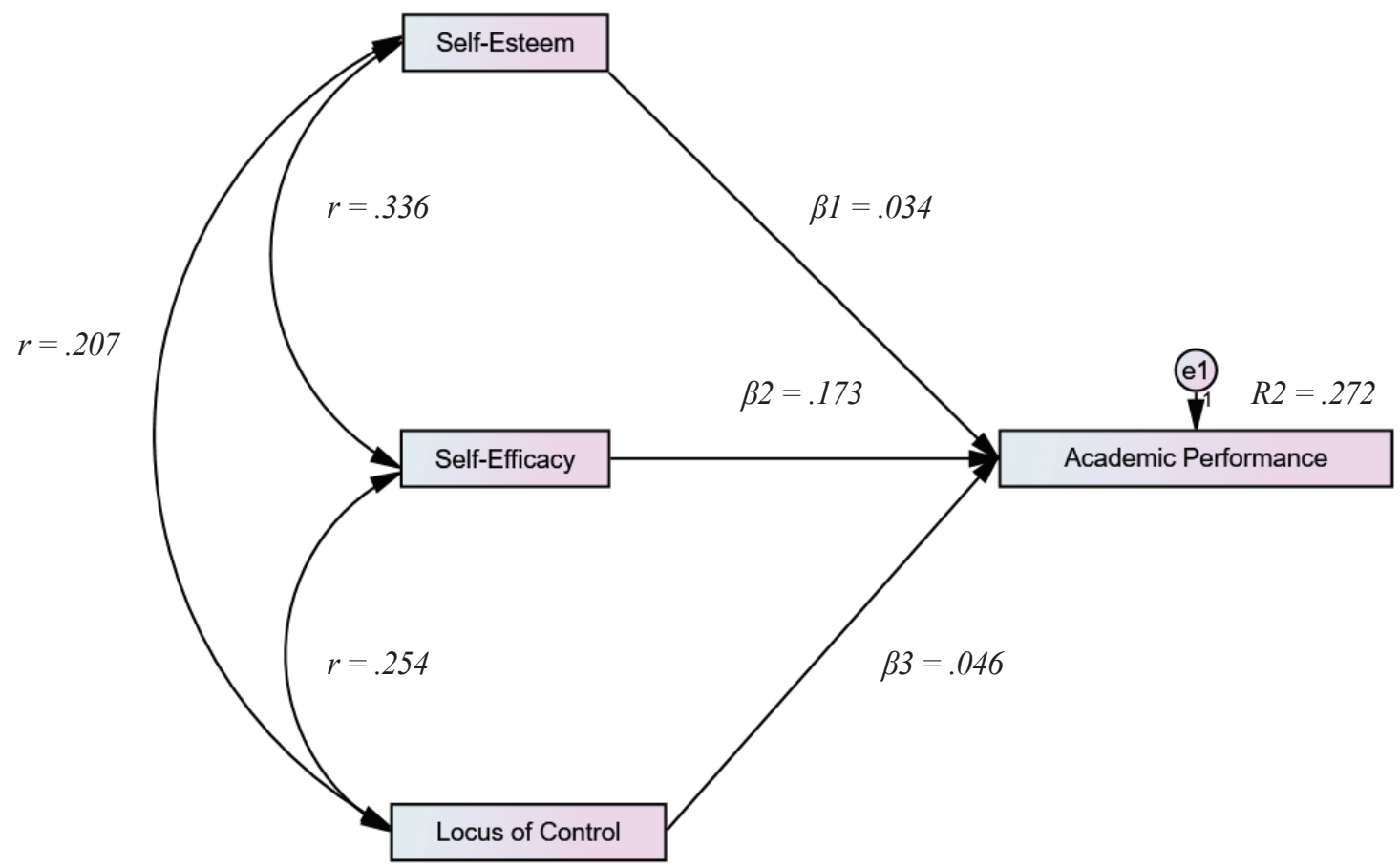

Note: $\mathrm{N}=452$

A structural equation model was developed and presented in Figure 2 to compute the combined effect of self-esteem, self-efficacy and locus of control as predictors of academic performance of the students. Figure 2 shows that the 
combination of three variables Self-Esteem $(\beta 1=.034)$, self-efficacy $(\beta 2=.173)$ and locus of control $(\beta 2=.046)$ accounted for $27.2 \%$ of the variance in academic performance $(\mathrm{R} 2=.272)$. The strongest predictor of academic performance is self-efficacy $(\beta 2=.173)$. Hence, the academic performance of graduate students can be predicted with the combination of three variables self-esteem $(\beta 1=.034)$, self-efficacy $(\beta 2=.173)$ and locus of control $(\beta 2=.046)$.

\section{Discussion}

A limited review of literature has revealed that there was no research available which measured the combined effects of self-esteem, self-efficacy and locus of control as predictors of academic performance of the students in the scenario of higher education. Hence, this research confirmed that all three variables self-esteem, self-efficacy and locus of control are significant predictors of the academic performance of the students in higher education through an equation of the regression model.

The academic performance of the students cannot be measured in isolation or with one or two variables of psycho-social determinant (Abid et al., 2014; Zahra, 2010). This study observed that students' self-esteem and self-efficacy were weakly correlated with the locus of control bearing no connection related to their gender but also depends on many social, psychological and individual latent factors (Ismail, 2017), availability of social support mechanism at home from parents and in-classroom from faculty members (Wokama et al, 2019).

This research found that male and female students expressed similar opinions about their self-esteem, self-efficacy, locus of control and academic performance. Many types of research in the literature found that male students reported higher self-esteem, self-efficacy and lower academic stress and depression than female students (Akram \& Ghazanfar., 2014, Hamaideh \& Hamdan-Mansour, 2014; Kanwal, 2006; Rady et al., 2016) which were contradictory to the findings of this research. Some researchers also reported about higher self-esteem among females students contributed to their higher Academic Performance than male students (Fatima \& Shafique, 2015; Zahra, 2010). These mixed findings in the literature showed that many cultural psychological, and economic latent variables directly affected the academic outcomes of the students in different social settings at the university level. 
The findings of this research differ with the study of Farhan and Khan, (2015) by reporting that the students of public sector universities expressed higher mean scores about self-efficacy, self-esteem, locus of control and academic performance than private sector universities in Karachi. This research confirms that public sector universities in Karachi foster the self-esteem, self-efficacy and Locus of Control that significantly affected Academic Performance. However, private sector universities in Karachi may impose restrictions and may be less flexible in academic environments and be more result-oriented in the perspective of students' success.

The previous researches in the literature confined their scope by reporting the correlation among Psycho-Social Determinants and Academic Performance of students in higher education (Batool, et al., 2017). This research confirms that self-esteem, self-efficacy and Locus of Control are positively correlated with the Academic Performance of graduate students in the context of higher education in Pakistan. Currently, there is no research available either to confirm or refute the reported findings of the t-test, Regression model and SEM regarding self-esteem, self-efficacy and locus of control as predictors of Academic Performance of graduate students.

\section{Conclusion and Recommendations}

This study showed that self-esteem, self-efficacy and locus of control are the significant and combined predictors of academic performance of the students in public and private universities of Karachi. Only one university in the private sector collects any information related to the psycho-social wellbeing of the students in Karachi. There is a strong need for the establishment of an organizational database in every university to collect the information related to the psycho-social wellbeing of students during the different phases of a semester. This research endorses that graduate students suffering from mental, psychological and social issues need meaningful assistance from counseling professionals, their parents at home, from teachers in their classroom and friends in their social circles. Finally, future studies are suggested about those latent variables affecting the academic performance of the students in the context of higher education in Pakistan.

The following recommendations will be helpful for teachers, academic 
managers of public and private universities in Karachi, students and parents:

1. The findings of this research suggest all public and private universities in Karachi to initiate or to activate the services of the Bureau of Guidance and Counselling immediately for the students especially at the beginning of every calendar year and at the end of every semester. This bureau should devise a mechanism or a research tool to measure the intensity of mental health of new and the present students in different programs. The obtained data should be used for the services of the guidance and counseling staff for awareness sessions, seminars and workshops for the students, parents and the present faculty members about how to effectively deal with social and psychological issues of students. Bureau of Guidance and Counselling in these universities should establish the organizational database to immediately collect the information from the students regarding their issues related to their psycho-social wellbeing.

2. This research recommends the appointment of student advisors among the faculty members in every department in every university to address student social, psychological and academic concerns within an empathetic environment.

3. This researcher recommends formal and informal activities in the universities for the parents' guidance and for the training of faculty members to broaden their understanding regarding the building of social support mechanism at home or in the university to facilitate students in building their Self-Esteem and Self-Confidence (Rady et. al., 2016) and for coping with academic stress.

4. This researcher recommends that teachers in different programs should involve students in more creative thinking processes, risk taking for difficult options in academics, challenging the norms and focusing on their academic success for their future roles (Zhang \& Postiglione, 2001).

\section{References}

Ahmed, I., \& Jabeen, S. (2011). Self-Efficacy: The predictor of educational performance among university students. Information Management and Business Review, 3(2), 57-62.

Akram, B., \& Ghazanfar, L. (2014). Self-efficacy and academic performance of the 
students of Gujrat University, Pakistan. Academic Research International, $5(1), 283$.

Arshad, M., Zaidi, S. M. I. H., \& Mahmood, K. (2015). Self-Esteem \& academic performance among university students. Journal of Education and Practice, 6(1), 156-162.

Asim, M., \& Akbar, N. (2012). A study on measuring the intensity level of attention deficit hyperactivity disorder (ADHD) among the Students of University of Karachi, Pakistan. Journal of Social Science and Humanities, 51(2), 223-234. https://jsshuok.com/oj/index.php/jssh/article/view/220

Batool, S. S., Khursheed, S., \& Jahangir, H. (2017). Academic procrastination as a product of low self-esteem: A mediational role of academic self-efficacy. Pakistan Journal of Psychological Research, 32(1), 195.

Benitez, J. D. (2017). Relationships among behavioral engagement, self-efficacy, academic achievement, and career choice among middle school Mathematics students: Race and gender differences. http://purl.flvc.org/fsu/fd/FSU_SUMMER2017_Diaz_fsu_0071N_14091.

Damani, S. S. (2018, January 28). Mental illness in Pakistan: A subject of stigma, ridicule and cultural insensitivity. Journal of Pioneering Medical Sciences Blogs.

https://blogs.jpmsonline.com/2018/01/28/mental-illness-in-pakistan-a-subj ect-of- stigma-ridicule-and-cultural-insensitivity/

Deb, S., Strodl, E., \& Sun, J. (2015). Academic stress, parental pressure, anxiety and mental health among Indian high school students. International Journal of Psychology and Behavioral Sciences, 5(1), 26-34.

Dontoh, J., Bakete, R. A., \& Babah, P. A. (2018). Social self-concept and academic performance of students: Evidence in two Ghanaian Colleges of Education. African Journal of Interdisciplinary Studies, 11(2), 78-85.

Farhan, S., \& Khan, I. (2015). Impact of stress, self-esteem and gender factor on students' academic achievement. International Journal on New Trends in Education and their Implications, 6(2), 143-156.

Fatima, M., \& Shafique, M. (2015). Health and academic performance of university students: Direct and mediating effect of social capital. Pakistan Journal of Commerce and Social Sciences (PJCSS), 9(2), 357-379. http://hdl.handle.net/10419/188202

Findley, S., \& Cooper, V. (1983). Academic locus of control: A relevant variable at tertiary level. Higher Education Journal, 5(8), 251-257. 
Hackett, G., Betz, N. E., Casas, J. M., \& Rocha-Singh, I. A. (1992). Gender, ethnicity, and social cognitive factors predicting the academic achievement of students in engineering. Journal of Counseling Psychology, 39(4), 527-534.

Hamaideh, S. H., \& Hamdan-Mansour, A. M. (2014). Psychological, cognitive, and personal variables that predict college academic achievement among health sciences students. Nurse Education Today, 34(5), 703-708.

Hasan, S. S., \& Khalid, R. (2014). Academic locus of control of high and low achieving students. Journal of Research \& Reflections in Education, 8(1), 22-33,

Husain, U. K. (2014). Relationship between self-efficacy and academic motivation. In International Conference on Economics, Education and Humanities (ICEEH'14) (pp. 10-11).

Ismail, M., Aziz, F. H., AB, M. F., Ismail, M. F., \& PM, A. S. (2017). The Relationship between Self-Efficacy and GPA Grade Scores of Students. International Journal of Applied Psychology, 7(2), 44-47. https:/doi.org/ 10.5923/j.ijap.20170702.03

Jackson, T., Weiss, K. E., \& Lundquist, J. J. (2000). Does procrastination mediate the relationship between optimism and subsequent stress? Journal of Social Behavior and Personality, 15(5), 203-212.

Kanwal, W. (2006). Impact of locus of control and self esteem on the academic achievement orientations of private and public sector university students. (Doctoral dissertation) at National University of Modern Languages (NUML) Islamabad.

Karaman, M. A., \& Watson, J. C. (2017). Examining associations among achievement motivation, locus of control, academic stress, and life satisfaction: A comparison of US and international undergraduate students. Personality and Individual Differences 1(11). 106-110. https://doi.org/10.1016/j.paid.2017.02.006

Wokoma, I. P., Treasure, H., Mathew's, G., \& Rowland, S. O. (2019). Relationship between self-concept, gender, class of study and socio-economic background on values orientation of secondary school students in obio akpor local government area. South Asian Journal of Marketing \& Management Research, 9(8), 99-118.

https://doi.org/10.5958/2249-877X.2019.00040.7

Masud, H., Ahmad, M. S., Jan, F. A., \& Jamil, A. (2016). Relationship between 
parenting styles and academic performance of adolescents: Mediating role of self-efficacy. Asia Pacific Education Review, 17(1), 121-131. https://doi.org/10.1007/s12564-015-9413-6

Nilson-Whitten, M. K., Morder, B., \& Kapakla, G. M. (2007). Relationship between locus of control, optimism and academic performance. In Proceedings of the Annual Conference of the New Jersey Counseling Association Eatontown, New Jersey.

Pekrun, R., Goetz, T., Titz, W., \& Perry, R. P. (2002). Academic emotions in students' self-regulated learning and achievement: A program of qualitative and quantitative research. Educational Psychologist, 37(2), 91-105. https://doi.org/10.1207/S15326985EP3702_4

Safaria, T., \& Ahmad, A. (2013). Effects of self-efficacy on students' academic performance. Journal of Educational, Health and Community Psychology, 2(1), 22-29.

Shahid, R., Jabeen, N., \& Ansari, N. (2016). Academic self-concept and academic achievement among undergraduates in universities of Pakistan: A gender perspective. The Sindh University Journal of Education-SUJE, 45(1). http://sujo-old.usindh.edu.pk/index.php/SUJE/article/view/2329

Snyder, C. J. (2016). The Relationship between Peer-Self Concept and Academic Self-Concept in Elementary Students: A Person-Oriented Perspective. (Doctoral dissertation). https://scholarcommons.sc.edu/etd/3976

Sterbin, A., \& Rakow, E. (1996). Self-Esteem, Locus of Control, and Student. Mid-South Educational Research Association. USA. https://files.eric.ed.gov/fulltext/ED406429.pdf

Zaidi, I. H., \& Mohsin, M. N. (2013). Locus of control in graduation students. International Journal of Psychological Research, 6(1), 15-20. http://www.scielo.org.co/scielo.php?pid=S201120842013000100003\&scri $\mathrm{pt}=$ sci_arttext\&tlng $=\mathrm{pt}$

Zahra, A. T. (2010). Relationship between self-concept and academic achievement of female bachelor degree students (Doctoral dissertation, Pir Mehr Ali Shah Arid Agriculture University Rawalpindi, Pakistan). http://prr.hec.gov.pk/jspui/bitstream/123456789/513/1/520S.pdf

Zhang, L. F., \& Postiglione, G. A. (2001). Thinking styles, self-esteem, and socio-economic status. Personality and Individual Differences, 31(8), 1333-1346. https://doi.org/10.1016/S0191-8869(00)00227-0 


\section{Citation of this Article:}

Javeria, W., \& Muhammad, A. (2020). Regression model on self-esteem, self-efficacy, locus of control as predictors of academic performance of students in higher education. Journal of Education and Educational Development. 7(2), 387-406. 


\section{Guidelines for Contributors}

The Journal for Education and Educational Development welcomes original empirical research by both established and emerging scholars to promote cross-disciplinary collaboration on topical issues of interest to academics, policy makers and the public at large. Please read carefully the Guidelines for Contributors and Manuscript Preparation Guidelines before finalizing and submitting the manuscript.

- Submit the manuscript to the Chief Editor through Journal Management System http://journals.iobmresearch.com/ index.php/JEED

- The submissions will be pre-reviewed by the editors and then screened through three in-depth blind review process by ascertaining the suitability of the manuscript for publication.

- Manuscript from an author can be published only once in two years.

- Addition of the authors shall not be entertained, once the initial manuscript is submitted.

- Authors will be given an opportunity to submit their revised drafts not more than three times.

The JoEED accepts original and unpublished manuscripts in the following forms:

Articles: Research papers of up to 4000-6000 words including visuals (black and white). Contributions exceeding this length may be discussed with the chief editor, prior to submission for special consideration owing to the work reported.

View Points \& Discussions: Write-up of 2000-2500 words dealing with introduction of a model, best practices, processes with immediate application in the respective field, critical analysis, opinion, discussion, field-related organizational or international experiences and perspectives.

Reports: Write-up of $2000-2500$ words in the area of on-going research, projects and conferences. 


\section{Manuscript Preparation Guidelines}

- Manuscript must be in English.

- Submission of the manuscript will be held to imply that it contains original unpublished work and is not submitted elsewhere for publishing.

- The submissions should be typed double-spacing using Times New Roman, font style 12 pts, abstract 12 pts italics, all headings bold and 12 pts, and margins of $2.5 \mathrm{~cm}$ ( 1 inch) on all four sides.

- Author's name, email affiliation, and cell no should be included on a separate page and must not appear anywhere (main text, header, footer) in the submitted contribution. This will facilitate the blind review process and would avoid delays.

- The abstract should not be more than 200 words and must comprehensively capture the contents of the complete paper.

- Five keywords should be included to classify and access your paper on digital forums.

- The manuscript should include all necessary and complete information within the main text, not as footnotes and endnotes.

- In-text citations/ quotations/tables/diagrams/ referencesshould follow the requirements of the Publication Manual of the American Psychological Association (7th ed.), which can be accessed from http://apastyle.org/

- At least 25 references are required for each article.

- Acknowledgement and information on grants received can be given before the reference section.

- The manuscript for publication should be uploaded through Journal Management System at http://journals.iobmresearch.com/index.php/JEED 
Institute of Business Management

Department of Education

College of Economics and Social Development

Korangi Creek, Karachi - 75190

Tel: (+92 -21) 111-002-004 Ext: 751

Fax: (+92-21) 35090968

Email: education.journal@iobm.edu.pk

http://jmsnew.iobmresearch.com/index.php/joeed/about 